\title{
LEGAL HARMONIZATION IN ASEAN ECONOMIC COMMUNITIES (LOOKING FOR THE BEST LEGAL HARMONIZATION MODEL)
}

\author{
Candra Irawan \\ Faculty of Law University of Bengkulu, Indonesia \\ E-mail : candrawan73@gmail.com
}

\begin{abstract}
ASEAN countries need to be encouraged to make responsive, effective, efficient, nondiscriminatory, and pro-competition regulations that are adjusted AEC Blueprint 2025. This means that each ASEAN country needs to harmonize regulations so that the rules that apply in each national territory do not conflict with each other and in line with AEC Blueprint 2025. There is no clear regulation system in force in ASEAN, nor is the legal harmonization mechanism and binding power of the AEC. Questions that should be asked, is the legal basis for the implementation of AEC Blueprint 2025 deliberately based on international agreements only (intergovernmental, soft law) and not upgraded to legal force (primacy principles, hard law)? The most important thing is that there is a shared awareness to build the ASEAN region's economy more productive, advanced and shared prosperity. The commitment is not enough just to use soft law approach, but must be followed by hard law approach (primacy principles). ASEAN leaders should hold talks and seek agreement to implement the principle of supranational (primacy principles) that the implementation of the AEC Blueprint 2025 be adhered to by all member states.
\end{abstract}

Keywords: Legal harmonization, Model, ASEAN, Economic Community

\section{Introduction}

The ASEAN Economic Community (AEC) agreed upon by ASEAN member countries on 31 December 2015 aims to create ASEAN economic integration. The agreement will be implemented following the AEC Blueprint 2025, signed by ASEAN Leaders at the 27th ASEAN Summit, November 22, 2015 in Kuala Lumpur, Malaysia. AEC is based on four pillars, namely: single market and unity of production base, competitive, innovative and dynamic economic region, equitable economic growth and ASEAN that is integrated in the global economy. ${ }^{1}$ The guarantee for the implementation of this matter has also been agreed that each ASEAN country may not withdraw the agreed commitment (no back loading of commitments) and the flexibility of some things that should be asked at the beginning of negotiations and must be approved together. $^{2}$ ASEAN member countries are

\footnotetext{
${ }^{1}$ ASEAN Secretariat, https://asean.org/aseaneconomic-community/aec-monitoring/, 26/09/2018.

2 Sjamsul Arifin, Rizal A. Djaafara and Aida S. Budiman (ed), ASEAN Economic Community 2015,
} 
required to ratify AEC Blueprint 2025 within 6 months. $^{3}$

AEC Blueprint 2025 should be supported by legal regulations. Therefore, ASEAN countries need to be encouraged to make responsive, effective, efficient, nondiscriminatory, and pro-competition regulations that are adjusted AEC Blueprint 2025. This means that each ASEAN country needs to harmonize regulations so that the rules that apply in each national territory do not conflict with each other and in line with AEC Blueprint 2025. There is no clear regulation system in force in ASEAN, nor is the legal harmonization mechanism and binding power of the AEC. Looks still very soft, given the freedom to ASEAN member countries to harmonize the regulations according to the needs of the level of economic development. This condition causes the implementation of AEC Blueprint 2025 to be slower.

Questions that should be asked, is the legal basis for the implementation of AEC Blueprint 2025 deliberately based on international agreements only (intergovernmental, soft law) and not

PT. Elex Media Komputindo and Kompas Gramedia, Jakarta, 2008, p. 18.

${ }^{3}$ ASEAN Secretariat, ASEAN Economic Community Blueprint 2025, The ASEAN Secretariat Public Outreach and Civil Society Division, Jakarta, 2015, Article 82 ix. upgraded to legal force (primacy principles, hard law) $?^{4}$.

\section{Results and Analysis}

\section{Legal Harmonization Model on The}

\section{European Community (Eu)}

The establishment of the EU began with a presentation from Robert Schuman (Minister of Foreign Affairs of France) regarding the importance of cooperation in the use of the European Coal and Steel Community (ECSC) on 9 May 1950. France is also ready to give part of its sovereignty to a supranational institution who manages ECSC, then European countries agree to join the European Economic Community (EEC) based on the Rome Agreement 1957. Carrying the principle of free movement of persons, goods, services and capital. ${ }^{5}$

Now, there are 28 member countries in EU. The EU organizational structure consists of the European Parliament, the Council of Ministers, the European Commission, the European Court and the European Audit European Audit Agency. Applicable law in the EU is divided into two, namely the

\footnotetext{
${ }^{4}$ The term soft law first appeared in diplomatic language in the 1980s, and was widely used in the context of international relations and international law. Soft law refers to a quasi-law instrument that does not have a legally perfect binding force, its binding power is weaker than the power of positive law. See Bryan H. Druzin, Why does Soft Law Have any Power Anyway?, Asian Journal of International Law, 7 (2017), https://www.cambridge.org/core/terms. https://doi.org/10.1017/S2044251316000229, p. 361.

${ }^{5} \mathrm{https}: / /$ europa.eu/european-union/abouteu/history_en, 27/09/2018.
} 
primary law which is the basic rule of all EU actions and secondary law includes regulations, directives and decisions based on the principles and objectives of the establishment of the EU. Legal issues that can hinder the achievement of EU objectives are overcome through the application of the primacy principle, community law has the primacy of national law. ${ }^{6}$ EU law has a higher position than the national law of member states. When there is a conflict between EU law and the national law of member countries, then EU law applies. ${ }^{7}$

\section{Legal Harmonization Model on The North} American Free Trade Area (Nafta)

NAFTA is an organization of countries of North America was founded in 1994 by the United States, Canada and Mexico. The goal is to eliminate trade barriers and facilitate cross-border movement of goods and services, creating fair competition, increase investment opportunities substantially in the member states, the protection and enforcement of intellectual property rights, create effective procedures for the implementation of the agreement, the administration of joint and settlement disputes, as well as establishing a trilateral,

\footnotetext{
${ }^{6} \mathrm{M}$. Budiarto, Basics of Economic Integration and Harmonization of European Community Law, CV. Akademika Pressindo, Jakarta, 1991, p. 46.

${ }^{7}$ Craig, Paul; De Burca, Grainne, Primacy of European Union law, https://www.revolvy.com/topic/Primacy\%20of\%20Eu ropean\%20Union\%20law, 27/09/2018.
}

regional and multilateral cooperation framework. ${ }^{8}$ Although in its founding charter led to the application of principles of primacy of Community law but in fact not the case. Even now NAFTA is headed for dissolution, the United States has stated that it is no longer interested in continuing economic cooperation through NAFTA. Such conditions show that in fact NAFTA countries did not make efforts to harmonize national law and NAFTA provisions, but to survive the national law and the national interests of each member country. Another fact, it actually resulted in a decrease NAFTA Mexico's economic growth (1.8\%) whereas before growing $3.2 \%$. The impact caused poverty for farmers in Mexico. ${ }^{9}$ This confirms that actually NAFTA has ended, failed.

\section{Obstacle Matters In The Implementation} of Law Harmonization

Countries in Asia including ASEAN are the new hemispheres of the world, and there is a shift in global power from west to east. This is inevitable, especially in the economic sector driven by China and India. ${ }^{10}$

\footnotetext{
${ }^{8}$ NAFTA Sec, North American Free Trade Agreement, https://www.nafta-sec-alena.org/Home/Texts-of-theAgreement/North-American-Free-Trade-Agreement?, 27/09/2018.

${ }^{9}$ Joseph E. Stiglitz, Making Globalization Work, Dealing with Globalization Towards a More Just World, Mizan Pustaka, 2007, p. 125.

${ }^{10}$ Khisore Mahbubani, The New ASIAN Hemisphere The Irresistible Shift of Global Power to East (Indonesian translation), Kompas, Jakarta, 2011.
} 
ASEAN strongly of potential to contribute greatly and benefited from the economic strength of Asia. ASEAN (AEC) is strong will be a tough competitor China, India, USA and EU.

The establishment of AEC, potentially generate US \$ 280 billion to $\$ 615$ billion (equivalent to 5 to $12 \%$ of the projected ASEAN GDP) in economic value annually in 2030. ASEAN would be the seventh largest economy in the world and is projected to rank the fourth largest economy in 2050. The attractiveness of the ASEAN region includes a population of 620 million $(9 \%$ of the world's population), the third largest workforce in the world (after China and India), and an average economic growth rate of around 5.4\% per year. ${ }^{11}$ Between 2007 and 2014, ASEAN trade increased by a value of nearly $\$ 1$ trillion. Most of that (24\%) was trade within the region, followed by trade with China (14\%), Europe (10\%), Japan (9\%) and the United States (8\%). During the same period, foreign direct investment (FDI) rose from $\$ 85$ billion to $\$ 136$ billion, and in share to the world from $5 \%$ to $11 \%$. With 622 million people ASEAN is the world's third largest market, which behind China and India has the third largest labour force. ${ }^{12}$

\footnotetext{
${ }^{11}$ http://finansial.bisnis.com/read/20150608/9/441313/ mea-2015-ini-dia-besaran-potensi-ekonomi-tantanganmasyarakat-ekonomi-asean, 30/09/2018.

${ }^{12} \mathrm{WEF}$, The ASEAN Economic Community: what you need to know https://www.weforum.org/agenda/2016/05/asean-
}

Predictions, projections and the potential for a positive impact on economic progress and prosperity for the people of ASEAN when countries have a shared commitment comply AEC Blueprint 2025. Some potential issues become an obstacle to the harmonization of laws on the AEC, namely:

1. The existence of different economic interests among ASEAN member countries. There is a problem of economic divergence in ASEAN countries. The economic divergence consists of four groups, namely: first group (Singapore), (2) second group (Thailand and Malaysia), third group (Indonesia, Philippines and Brunei), fourth group (Cambodia, Laos, Myanmar and Vietnam). ${ }^{13}$

2. Strengthening of protectionism against national economic interests. Actually, not all economic activities are global. International trade, although it has been echoed as having embraced global trade, turns out that the reality is largely regional, EU countries trade with their members, and trade less with other countries. $^{14}$ Economic globalization is most evident in international financial

economic-community-what-you-need-to-know/, 30/09/2018.

${ }^{13}$ Sjamsul Arifin, Rizal A. Djaafara and Aida S. Budiman (ed), Op.,Cit, p. 61.

${ }^{14}$ Anthony Giddens, The Third Way (Third Way of Social Democracy Renewal), PT. Gramedia Main Library, Jakarta, 2000, p. 33. 
marketsl. ${ }^{15}$ Currently, the WTO suffered a severe test by the emergence of the US president's policies, Donald Trump (Trump Policy) that carries the highly protectionist and threatens in the free trade in the world. For example, the policy plan for the implementation of trade tariffs is higher for China, EU, Mexico and Canada. ${ }^{16}$ The United States Government on September 24, 2018 implemented an import tariff of $10 \%$ on 5745 imported products from China valued at USD 200 billion. The action was immediately repaid by China by applying import tariffs on 5207 imported products from the United States at a rate of $5 \%-10 \%$ equivalent to USD 60 billion. $^{17}$ For Indonesian products, it is also planned to be subject to higher import duties for 124 Indonesian products. ${ }^{18}$ However, concerns about the Trump Policy effect are contagious to AEC member countries. Foreign Ministers of ASEAN countries declared their opposition to economic protectionism. $^{19}$

\footnotetext{
${ }^{15}$ Ibid, p. 35 .

${ }^{16} \mathrm{https} / / / \mathrm{www} \cdot \mathrm{bbc} . \mathrm{com} /$ indonesia/indonesia43620873, 28/09/2018.

${ }^{17}$ Editor, Real Trade War, Kompas, Tuesday, 09/25/2018.

${ }^{18}$ https://www.liputan6.com/bisnis/read/3583579/strate gi-ri-hadapi-ancaman-bea-masuk-as, 28/09/2018. ${ }^{19} \mathrm{https}$ ://www.cnnindonesia.com/internasional/201808 03154949-113-319276/asean-china-sepakat-tolakproteksionisme-perdagangan?, http://waspada.co.id/warta/jaga-perang-dagang-asasean-china-sepakat-tolak-proteksionismeperdagangan/, 28/09/2018.
}

3. Increased escalation of economic competition and depletion of shared commitments. Reflecting on the case of British (Brexit) in the EU and the failure of NAFTA, it turns out that joining an economic community does not eliminate competition between member countries, and because the national economic interests of certain countries are threatened, the shared commitment to advance the economic community is diminishing. As a result there is an economic conflict. The best solution is cooperation and trying to minimize the gap between member countries. The problem of the economic community is not able to be solved only by the government but it is important to invite actors outside the country (economic actors, investors, employers' associations, non-government institutions). ${ }^{20}$

4. Unclear legal harmonization model of AEC (soft law approach). Studying the ASEAN establishment charter to AEC 2015, the approach used is the intergovernmental approach. All the problems arising from the implementation of the AEC disconnected in meetings and negotiations between the government, there is no body set up as an official body of dispute resolution. The ASEAN

\footnotetext{
${ }^{20} \mathrm{~T}$. May Rudi, Contemporary International Relations and Global Problems, PT. Refika Aditama, Bandung, 2003, p. 3.
} 
Secretariat does not have this authority. harmonization substantive rules related to The ASEAN structure consists of: economic activities. ${ }^{22}$ So far, at a meeting of ASEAN Summit, Organizational ASEAN leaders (AEC) has never been Structure, ASEAN Coordinating Council, discussed seriously in the implementation of ASEAN Community Councils, ASEAN the AEC the desire to change the way of Sectoral Ministerial Bodies, Committee of Permanent Representatives, National Secretariats, ASEAN Committees in Third Countries and International Organizations (ACTCs). ${ }^{21}$ The difference is in the supranational authority of the EU.

\section{Legal Harmonization Model in Asean}

\section{Economic Communities (A Proposal)}

The most crucial issue in the process of legal harmonization in the international economic community such as the AEC, even faced by the United Nations (UN) is that national laws are often different or contradictory to the national laws of other member countries. Differences or contradictions originating from national law can lead to disputes and become obstacles to the AEC agenda. There are at least three ways that can be done, namely: (1) ASEAN member countries (AEC) agree not to apply their national laws, and declare that they are subject to the AEC rules, (2) use their respective national laws and in the event of a dispute agree to apply the choice of law principle, and (3) carry out unification and

\footnotetext{
${ }^{21}$ https://asean.org/asean/asean-structure/, 28/09/2018.
} towards a supranational approach. ASEAN countries do not want to hand over some of the sovereignty in the economic field to the AEC institution. So it is natural, if the achievement of the AEC 2025 Blueprint takes place slowly and is difficult to be fully realized by 2025 . Many agreements are made by ASEAN, but there is no special institution that can supervise and enforce the compliance of member countries to the implementation of the agreement. ASEAN does not have an institution that can call on member countries that are not compliant with the agreement. There is no credible mechanism in resolving disputes objectively and is strongly binding. ${ }^{23}$

In fact, the harmonization of law in international relations has been carried out, including: by the United Nations (UN) through the United Nations Conference on Trade and Development (UNCTAD), the International Center for Trade and Sustainable Development (ICTSD) and the

\footnotetext{
${ }^{22}$ Huala Adolf, International Trade Law, PT. Rajagrafindo Persada, Jakarta, 2006, p. 30.

${ }^{23}$ Koesrianti, Analysis of the Strength of the ASEAN Charter and the Development of the Dispute Settlement Mechanism in ASEAN, Yuridika Journal Volume 26 No 1, January-April 2011, EJournal.Unair.Ac.Id/Index.Php/Ydk/Article/Download /262/140, 30/09/2018.
} 
United Nation Conference on International Trade and Law (UNCITRAL). Various international conventions produced by these bodies are widely adopted by countries in the world into positive law, ${ }^{24}$ by the World Trade Organization (WTO) is based on the principle of complete submission, to the offense may be filed a lawsuit to the WTO Dispute Settlement Body, and if found guilty, sentenced to fines. The problem is on the existence of differences in the legal system and the substance of the national laws of member countries, the legal requirements for member states are not the same. ${ }^{25}$

According to the author's thoughts, reflect on the case of the EU and NAFTA, the model law harmonization is right for the AEC is to integrate the construction model EU law (hard law) and to areas of the economy that are sensitive approach over (soft law) through negotiation on an ongoing basis to ASEAN member countries is ready and agreed to be jointly subject to hard law rules. The construction model of EU (hard law) law can be used for certain economic fields where all AEC countries are ready. For example, investment and trade licensing standards, recognition of certain expertise certifications issued by the AEC state certification agency, labor law protection

\footnotetext{
${ }^{24}$ Kusnu Goesniadhie, Harmonization of Law in the Perspective of Regulations (Lex Specialist, A Problem), JP Books, Surabaya, 2006, p 106.

${ }^{25}$ Candra Irawan, Political Law of intellectual property rights, CV. Mandar Maju, Bandung, 2012, p. 94.
}

standards, quality standards for goods and services products, tariff reductions and elimination of tariffs on goods produced by AEC countries.

\section{Conclusion}

The most important thing is that there is a shared awareness to build the ASEAN region's economy more productive, advanced and shared prosperity. The commitment is not enough just to use soft law approach, but must be followed by hard law approach (primacy principles). ASEAN leaders should hold talks and seek agreement to implement the principle of supranational (primacy principles) that the implementation of the AEC Blueprint 2025 be adhered to by all member states.

\section{References}

ASEAN Secretariat, https://asean.org/aseaneconomic-community/aecmonitoring/, 26/09/2018.

Sjamsul Arifin, Rizal A. Djaafara and Aida S. Budiman (ed), (2008), ASEAN Economic Community 2015, PT. Elex Media Komputindo and Kompas Gramedia, Jakarta.

ASEAN Secretariat, (2015), ASEAN Economic Community Blueprint 2025, The ASEAN Secretariat Public Outreach and Civil Society Division, Jakarta.

Bryan H. Druzin, (2017), Why does Soft Law Have any Power Anyway?, Asian Journal of International Law, 7, https://www.cambridge.org/core/ter ms.https://doi.org/10.1017/S204425 
1316000229 ,

p.

https://europa.eu/european-

union/about-eu/history_en,

27/09/2018.

M. Budiarto, (1991), Basics of Economic Integration and Harmonization of European Community Law, CV. Akademika Pressindo, Jakarta.

Craig, Paul; De Burca, Grainne, Primacy of European Union law, https://www.revolvy.com/topic/Prim acy\%20of\%20European\%20Union \%201aw, 27/09/2018.

NAFTA Sec, North American Free Trade Agreement, https://www.nafta-secalena.org/Home/Texts-of-theAgreement/North-American-FreeTrade-Agreement?, 27/09/2018.

Joseph E. Stiglitz, (2007), Making Globalization Work, Dealing with Globalization Towards a More Just World (Indonesian translation), Mizan Pustaka.

Khisore Mahbubani, (2011), The New ASIAN Hemisphere The Irresistible Shift of Global Power to East (Indonesian translation), Kompas, Jakarta.

http://finansial.bisnis.com/read/20150608/9/4 41313/mea-2015-ini-dia-besaranpotensi-ekonomi-tantanganmasyarakat-ekonomi-asean, 30/09/2018.

WEF, The ASEAN Economic Community: what you need to know, https://www.weforum.org/agenda/201 6/05/asean-economic-communitywhat-you-need-to-know/, 30/09/2018.

Anthony Giddens, (2000), The Third Way (Third Way of Social Democracy Renewal), PT. Gramedia Main Library, Jakarta. https://www.bbc.com/indonesia/indonesia43620873, 28/09/2018.

Editor, Real Trade War, Kompas, Tuesday, 09/25/2018.

https://www.liputan6.com/bisnis/read/35835 79/strategi-ri-hadapi-ancaman-beamasuk-as, 28/09/2018.

https://www.cnnindonesia.com/internasional/ 20180803154949-113319276/asean-china-sepakat-tolakproteksionisme-perdagangan?, http://waspada.co.id/warta/jagaperang-dagang-as-asean-chinasepakat-tolak-proteksionismeperdagangan/, 28/09/2018.

T. May Rudi, (2003), Contemporary International Relations and Global Problems, PT. Refika Aditama, Bandung.

https://asean.org/asean/asean-structure/, 28/09/2018.

Huala Adolf, (2006), International Trade Law, PT. Rajagrafindo Persada, Jakarta.

Koesrianti, Analysis of the Strength of the ASEAN Charter and the Development of the Dispute Settlement Mechanism in ASEAN, Yuridika Journal Volume 26 No 1, January-April 2011, EJournal.Unair.Ac.Id/Index.Php/Ydk/ Article/ Download/262/140, 30/09/2018.

Kusnu Goesniadhie, (2006), Harmonization of Law in the Perspective of Regulations (Lex Specialist, A Problem), JP Books, Surabaya.

Candra Irawan, (2012), Political Law of Intellectual Property Rights, CV. Mandar Maju, Bandung.. 